\title{
What Influences Decision on Seasoned Equity Offerings of Listed Vietnamese Companies?
}

\author{
Long Hau LE ${ }^{1}$, Thi Binh Nhi NGUYEN², Xuan Quynh PHAM${ }^{3}$, Quoc Duy VUONG ${ }^{4}$, Tan Nghiem LE
}

Received: February 21, 2020 Revised: March 08, 2020 Accepted: April 03, 2020

\begin{abstract}
This paper investigates the determinants on decision to conduct seasoned equity offerings (SEOs) of listed companies on the Ho Chi Minh Stock Exchange in Vietnam. Seasoned equity offerings (SEOs) are defined as the issue of more stocks by a firm to raise more capital after a primary issue. Using panel data collected from audited financial statements of 99 listed companies on the Ho Chi Minh Stock Exchange during 2014-2018, the study employs a logit regression model by fixed effects method to examine factors that affect the decision to implement seasoned equity offerings of those companies. The findings of this study show that profit, revenue growth and company's size have a positively significant impact on the decision, while dividend pay-out ratio negatively significantly influences the equity issuing decision. Furthermore, these results are robust after controlling for the forms of equity offerings, i.e. bonus stocks, stock dividends and rights to buy shares. These findings are consistent with economic theories such as agency theory, pecking order theory, and growth opportunity theory, and also could be explained by the real situations of the Vietnamese stock exchange. This study has important implications for corporate managers, policy makers and investors.
\end{abstract}

Keywords: Vietnam, Stock Market, Seasoned Equity Offerings, Dividend Pay-Out Ratios

JEL classification code: B26, G23, G30, G31, G34

\section{Introduction}

In the market economy, in order to survive and grow, the companies must have strong financial resources. There are various ways for companies to increase their financial resources such as utilizing endogenous funds (profits, depreciation), borrowing debts or offering equity on the stock market. Among those choices, seasoned equity offerings

${ }^{1}$ First Author and Corresponding Author. College of Economics, Can Tho University, Vietnam [Postal Address: Campus II, 3/2 Street,

Ninh Kieu District, Can Tho City, 900000, Viet Nam]

Email: Ilhau@ctu.edu.vn

${ }^{2}$ College of Economics, Can Tho University, Vietnam.

Email: nhim2717027@gstudent.ctu.edu.vn

${ }^{3}$ Faculty of Economic and Business Administration, An Giang

University, VNU-HCM, Vietnam. Email: pxquynh@agu.edu.vn

${ }^{4}$ College of Economics, Can Tho University, Vietnam.

Email: vqduy@ctu.edu.vn

${ }^{5}$ College of Economics, Can Tho University, Vietnam.

Email: tannghiem@ctu.edu.vn

(c) Copyright: The Author(s)

This is an Open Access article distributed under the terms of the Creative Commons Attribution Non-Commercial License (http://Creativecommons.org/licenses/by-nc/4.0/) which permits unrestricted noncommercial use, distribution, and reproduction in any medium, provided the original work is properly cited.
(SEOs) are usually a possibility for listed companies to raise capital from the stock market. By definition, seasoned equity offerings (SEOs) are the issue of more stocks by a firm after a primary issue. In order to achieve the greatest benefits from share offerings, the management team of a company must consider many factors such as market stock prices, issuing time, forms of offerings, etc.

A number of financial theories have been put forward to explain for decision to seasoned equity offerings by companies. For examples, with agency problem theory, Jensen and Meckling (1976) has proposed that the choice between issuing equity and borrowing debts to mobilize additional funds by companies depends on the representative costs of equity and debts at the decision time. Pecking order theory explains the financing decisions of companies on the basis of asymmetric information, in which management team only considers the use of seasoned equity offerings to finance for company's investment when the company's shares are being overvalued in the market (Myers, 1984). Growth opportunity theory attributes the equity offerings decisions to the presence of promising investment opportunities in a company. Owning a good investment project is considered as positive information for investors, which will cause the 
stock prices to be uptrend. Therefore, a company with growth potentials often favors financing for its investment projects through a stock offering to avoid a shift in shareholder funding to creditors (Myers, 1977).

From the corporate governance perspectives, market timing theory assumes that the administrators take advantage of corporate insider information, based on the market price deviation from the true value of shares, will proceed to adjust the time of stock offerings. In other words, managers, at the time of stock market overpriced, will choose to issue more stocks (Baker \& Wurgler, 2002). Moreover, according to the Choe, Masulis, and Nanda (1993), the decision to issue more stocks is often implemented under the good times of the economy. Along with those theories, many empirical studies have been conducted for companies over the world such as Chikolwa and Kim (2009), Huang (2012), Virolainen (2009), Abraham and Harrington (2011), among others, showing various factors affecting the decision to offer equity and forms of equity offerings. However, this issue has not yet received a lot of attention for listed companies on the Vietnamese stock market, especially on the Ho Chi Minh Stock Exchange (HOSE). The study is conducted to fill this gap of the literature.

The structure of the paper is as follows. Section 2 reviews the related literature of the research issue. The methodology is described in Section 3, followed by empirical results and discussions in Section 4. Finally, we provide some concluding remarks in Section 5.

\section{Literature Review}

Seasoned equity offerings to the public by companies can be split into two forms: stock dividend or issuing bonus stocks, and issuing rights to buy shares for existing shareholders. More specifically, stocks dividend or issuing bonus stocks is a way to transfer retained earnings into equity capital of the company. This simply helps the company to save a large amount of cash paid to shareholders, leaving the size of the company's owner capital unchanged. As for the issuing of rights to buy shares, the company likes to raise more cash to increase its equity capital (owner capital), also leading to the increase in the number of outstanding stock of the company.

The literature has shown a number of determinants of decision to seasoned equity offerings. Return of company is one of the main factors influencing its equity offering decisions. High profit companies may have less motivation to issue more stocks because they may have sufficient internal financial resources to finance their capital needs (Elliott, Koëter-Kant, \& Warr, 2008; Alti \& Sulaeman, 2012; Nguyen, Bui, \& Pham, 2019). Furthermore, high profit companies may have to pay high taxes, therefore, they may tend to meet their capital needs by loan to exploit the benefits of the tax shield. However, according to Chikolwa and Kim (2009), it is possible that companies like to enlarge their businesses as they get a higher ratio of profit. Thus, a high profit company may have a higher possibility to offer more stocks. The theory of growth opportunity states that as companies have a higher turnover growth they may be ambitious to invest more in new projects, forcing them to seek more external financial resources in order to meet their capital demands. These companies tend to issue more shares to raise capital instead of borrowing debts to minimize the sharing of benefits between shareholders and creditors, and also to mitigate any financial difficulties that may arise from financing by debts. This theory has also been verified by Bo, Huang, and Wang (2011), Barclay and Smith (1995), Rajan and Zingales (1995), and Vijayakumaran and Vijayakumaran (2019).

Another factor affecting the decisions to seasoned equity offerings by firm is the market-to-book-value ratio. This stems from the fact that managers will choose the time when the companies' shares are overpriced to issue more shares. The given market conditions may help the company reducing the costs of capital, increasing the benefits for existing shareholders, reducing the possibility of issuing new capital to external shareholders (Jung, Kim, \& Stulz, 1996; Elliott, KoëterKant, \& Warr, 2008; Alti \& Sulaeman, 2012). Additionally, management's shareholding rate is also considered as a factor that influences seasoned equity offerings choice. The manager's shareholding rate includes the holdings' rates of the director board and the executive board to the total number of shares issued. According to the agency theory, the lower the rate of stocks the managers hold, the more conflict between managers and shareholders becomes. This conflict causes the managers to increase their control of power.

As a result, they may use the stock issuance to exploit more financial resources from the minority shareholders and enhance their control power. In many cases, large shareholders, company managers often use the issue of new shares to increase the proportion of their ownership in the company in order to occupy the company and to take away part of the assets of the company (Jung, Kim, \& Stulz, 1996; Bo, Huang, \& Wang, 2011). As for company size, Huang (2012); Vu, Phan, and Dang (2020) states that the larger companies, the more stable the earnings, these companies may easily obtain more loan sources, so the probability that the company proceeds to seasoned stock offerings is less likely to occur. Elliott, Koëter-Kant, and Warr (2008) also shows that the larger the company is, the more financial information transparency it has, resulting in the more stable company's assets is. This may help the company easily accessing to low interest loans; therefore, it may prioritize borrowing rather than implementing additional issues.

However, McLaughlin, Safieddine, and Vasudevan (1996) find that the company size has a positive correlation with the decision to issue more shares. Regarding the financial 
leverage ratio of a company, Abraham and Harrington (2011), and Gul and Cho (2019) believe that an increase in long-term debt can affect risk management activities of the company, which may reduce the ability to use the company's future cash flows. Thus, the company with a high financial leverage may avoid the cost of financial distresses by issuing more stocks to support its financial needs (Alti \& Sulaeman, 2012). Dividend payout ratio is another factor that is put forward in the literature as a determinant of seasoned equity offerings choice. Particularly, a high dividend payout ratio is a positive signal about the company's financial capability to maintain the distribution of cash to shareholders, as well as the benefits that shareholders expect to get from the ongoing success of the company. Commonly, dividends are used as a way to signal corporate value, which helps to increase the company's share prices in the market. It is a stylized fact that most of companies (except for low value companies) have declared dividends before seasoned stock offerings (John \& Williams, 1985). On the contrary, Loderer and Mauer (1992) demonstrate that companies deciding to conduct seasoned stock offerings are less likely to pay or increase dividends than those being not. The argument is that the issuing company paying no dividends or low dividend may have relatively more valuable investment opportunities than high dividend paying ones.

\section{Research Methodology}

\subsection{Model}

Following the literature, the empirical model to investigate determinants on the decision to conduct seasoned equity offerings by companies is presented as follows:

$$
\begin{aligned}
S E O_{i, t}= & \beta_{0}+\beta_{1} \text { ROA }_{i, t-1}+\beta_{2} R E V G_{i, t-1}+\beta_{3} M B_{i, t-1} \\
& +\beta_{4} \text { MHold }_{i, t-1}+\beta_{5} \operatorname{SIZE}_{i, t-1} \\
& +\beta_{6} D A_{i, t-1}+\beta_{7} D I V_{i, t-1}+\varepsilon_{i, t}
\end{aligned}
$$

Where $\mathrm{SEO}_{\mathrm{i}, \mathrm{t}}$ is a binary variable, being equal to 1 if company $\mathrm{i}$ conducts seasoned equity offerings in year $\mathrm{t}$ and 0 , otherwise; $\mathrm{i}$ symbolizes for individual company and $\mathrm{t}$ represents for time; $\beta \mathrm{s}$ are estimated coefficients; and all the independent variables are shown in Table 1.

\subsection{Data}

Panel data are collected from the audited financial statements of 99 listed companies on HOSE over the period of 2014-2018. Companies in the sample are selected based on the following criteria: (i) listed companies must implement seasoned equity offerings during the research period; and (ii) financials are not included in the sample because their balance sheet structure is completely different from that of industrials.

\subsection{Estimated Method}

Logit regression model with panel data is estimated by both the fixed effects method (FEM) and random effects method (REM), and the appropriate method is selected using Hausman test. Multicollinearity of the regression is tested by VIF (Variance Inflation Factor). In addition, the tests related to the reliability of the regression model are also appropriately carried out.

\section{Results and Discussions}

\subsection{Correlation Analysis}

Table 2 shows the correlation coefficients between independent variables in the regression model. In general, all the correlation coefficients between independent variables have absolute values less than 0.8 , indicating that multicollinearity is not a serious problem affecting the estimation results of the model (Gujarati, 2004).

Table 1: Definition of independent variables

\begin{tabular}{|l|l|l|c|}
\hline \multicolumn{1}{|c|}{$\begin{array}{c}\text { Independent } \\
\text { variables }\end{array}$} & \multicolumn{1}{c|}{ Definition } & \multicolumn{1}{c|}{ Sign } \\
\hline ROA & Returns on assets & Net returns/total assets & $+/-$ \\
\hline REVG & Revenue growth rate & $($ Revenue yeart/Revenue yeart-1)-1 & + \\
\hline MB & Market-to-book value ratio & Market value/Book value of stocks & + \\
\hline MHold & Management's shareholding rate & $\begin{array}{l}\text { Number of shares owned by director and executive } \\
\text { board/Total company's shares }\end{array}$ & + \\
\hline SIZE & Company size & Logarithm of total assets & $+/-$ \\
\hline DA & Leverage ratio & Total debts/Total assets & + \\
\hline DIV & Cash dividend ratio & Cash dividends/Face value of stocks & $+/-$ \\
\hline
\end{tabular}


Table 2: Correlation matrix between independent variables

\begin{tabular}{|l|c|c|c|c|c|c|c|}
\hline & SIZE & ROA & DA & REVG & MB & DIV & MHold \\
\hline SIZE & 1.0000 & & & & & & \\
\hline ROA & -0.1039 & 1.0000 & & & & & \\
\hline DA & 0.2279 & -0.5314 & 1.0000 & & & & \\
\hline REVG & 0.0973 & -0.0514 & 0.0668 & 1.0000 & & & \\
\hline MB & 0.2310 & 0.5626 & -0.1814 & -0.0225 & 1.0000 & & \\
\hline DIV & -0.0838 & 0.7455 & -0.2902 & -0.0702 & 0.4470 & 1.0000 & \\
\hline MHold & -0.0287 & 0.0024 & 0.1363 & -0.0374 & 0.0419 & -0.0327 & 1.0000 \\
\hline
\end{tabular}

\subsection{Descriptive Statistics}

The descriptive statistics for all variables are shown in Table 3. As can be seen from the table, mean values of all variables are approximately equal between the two groups, i.e., seasoned equity offerings and non-seasoned equity offerings, except for ROA and REVG. While ROA of the seasoned equity offerings group is slightly higher than that of the non-seasoned equity offerings group (8.249 vis-à-vis 6.902), REVG of the former is very much larger than that of the latter (8.249vis-à-vis 6.902). These results indicate that seasoned equity offerings group seems to have better performance than the other group.

\subsection{Research Findings and Discussion}

\subsubsection{Main Results}

The estimation results are presented in Table 4. Some important points are worth noting. First, given the very low VIF statistics (that is, from 1.02 to 3.65 , which is much smaller than 10) for the regressions, it can be concluded that there is no evidence of multicollinearity. Second, the Hausman test results show that the FEM model is more appropriate than REM. Thirdly, the Wald statistics for a groupwise heteroskedasticity diagnostic test are highly statistically significant at the one percent level, indicating

Table 3: Descriptive statistics for all variables

\begin{tabular}{|l|c|r|r|r|r|}
\hline \multicolumn{1}{|c|}{ Variable } & Observations & Mean & Standard errors & Minimum & Maximum \\
\hline Panel A: Seasoned equity offerings \\
\hline ROA & 234 & 8.249 & 6.614 & -6.632 & 35.650 \\
\hline REVG & 234 & 43.093 & 177.213 & -57.215 & 2467.571 \\
\hline MB & 234 & 1.589 & 1.246 & 0.250 & 8.136 \\
\hline MHold & 234 & 0.292 & 0.237 & 0.002 & 1.649 \\
\hline SIZE & 234 & 6.405 & 0.534 & 5.296 & 8.330 \\
\hline DA & 234 & 50.643 & 19.356 & 3.098 & 90.481 \\
\hline DIV & 234 & 0.112 & 0.126 & 0 & 0.600 \\
\hline Panel B: Non seasoned equity offerings & \multicolumn{5}{|l|}{} \\
\hline ROA & 261 & 6.902 & 8.405 & -12.342 & 78.370 \\
\hline REVG & 261 & 17.050 & 52.628 & -82.847 & 421.807 \\
\hline MB & 261 & 1.346 & 1.195 & 0.186 & 12.681 \\
\hline MHold & 261 & 0.284 & 0.246 & 0 & 1.739 \\
\hline SIZE & 261 & 6.257 & 0.498 & 5.228 & 7.863 \\
\hline DA & 261 & 50.670 & 21.152 & 2.705 & 96.315 \\
\hline DIV & 261 & 0.155 & 0.192 & 0 & 2.140 \\
\hline
\end{tabular}


that significant heteroskedasticity across firms is present. Hence, the regression model is estimated by taking into account this heteroskedasticity, that is, using cluster-robust standard errors, clustering by the panel variable.

Results from the logit regression model are presented in Table 4. As can be seen from the results, variables comprising of company size (Size), returns on assets (ROA), revenue growth rate (REVG) and dividend ratio (DIV) are statistically significant from $1 \%$ to $10 \%$ levels, while the others (MB, MHold and DA) are not statistically significant. More specifically, the coefficient of SIZE is positively significant at $1 \%$ level, indicating that company size has a positively significant influence on the company's decision to issue additional shares. Obviously, large companies may have more advantages in raising capital than small ones, because they often diversify their businesses, have stable cash flows, and are also less likely to fail than smaller ones. Moreover, the larger the company, the more it may have greater opportunities of communicating positive information to outside investors, thereby bringing it more advantages when mobilizing capital through issuing additional shares (McLaughlin, Safieddine, \& Vasudevan, 1996).

As for ROA, its estimated coefficient is positively statistically significant at the 5\% level. This result is in contrast to the prediction of the pecking order theory

Table 4: Results from logit regression model with FEM

\begin{tabular}{|l|c|c|c|}
\hline \multicolumn{1}{|c|}{ Variable } & $\boldsymbol{\beta}$ & Dy/dx & VIF \\
\hline Size & $\begin{array}{c}3.210^{* * *} \\
(3.28)\end{array}$ & 0.120 & 1,20 \\
\hline ROA & $\begin{array}{c}0.166^{* *} \\
(2.45)\end{array}$ & 0.040 & 3.65 \\
\hline REVG & $\begin{array}{c}0.003^{*} \\
(1.79)\end{array}$ & 0.001 & 1.02 \\
\hline MHold & $\begin{array}{l}0.324 \\
(1.00)\end{array}$ & 0.016 & 2.37 \\
\hline DA & $\begin{array}{c}0.524 \\
(0.80)\end{array}$ & -0.017 & 1.04 \\
\hline DIV & $\begin{array}{c}-0.014 \\
(-0.74)\end{array}$ & 0.003 & 1.58 \\
\hline $\begin{array}{l}R^{2}=0.158 \\
\text { Wald- } X^{2}=40.87 \\
P \text {-value }(F)=0.0000 \\
\text { Observations: } 495 \\
\text { Estimated probability: } 62.83 \%\end{array}$ & $-1.491^{* * *}$ & -1.860 & 2.35 \\
\hline
\end{tabular}

Notes: the notations ", "* and "** denote the significance levels of $10 \%, 5 \%$ and $1 \%$, respectively; $z$-statistics are robust z-statistics after correcting for heteroskedasticity shown in parentheses. that the company's profit is negatively correlated with its decision to employ seasoned equity offerings. The argument is that the more profitable a company is, the more likely it will have more internal resources, therefore, the external financing such as borrowing debts or issuing shares become less important. However, given the real situations of Vietnam, this result can be explained as follows. Since the stock market of Vietnam is still young and less developed, and remain high speculative incentives, the company's profit can be seen as its bright future prospects to the market. Taking advantage of this, the more profitable listed companies may be issuing more shares to attract investors.

This result is also consistent with previous studies of Chikolwa and Kim (2009), and Ha (2017). Regarding the estimated coefficient of REVG, it is positive and statistically significant at the $10 \%$ level, showing a positive relationship between the seasoned equity offerings choice by a company and its revenue growth. This could be explained that companies with high revenue growth rates are often in the period of strong growth, increased market share and expansion in scale of operations. On the other hand, companies with high growth opportunities may be motivated to issue shares to finance new projects, meeting the needs of investors. Besides, issuing additional shares instead of borrowing debts may help the company minimize the benefits sharing between shareholders and creditors. This finding is consistent with previous studies (Bo, Huang, \& Wang, 2011; Huang, 2012; Barclay \& Smith, $1995)$ as well as growth opportunity theory. Finally, the coefficient of DIV is negative and statistically significant at the $1 \%$ level, indicating that the dividend payout ratio is negatively related to the decision to issue additional shares. This could be explained by the fact that companies with a low dividend payout ratio may possess many investment opportunities, since they tend to retain profits to invest in new potential projects to generate higher profits in the future. Those high potential companies are also in high demand of capital, therefore they have a higher incentive for additional issuance. This result is consistent with the study of Loderer and Mauer (1992).

\subsubsection{Robustness Checks}

Along with the decision to issue additional shares, the choice of forms of issuance, i.e., rights or stock dividend/ bonus shares, is also important for companies, since this decision may depend on company's characteristics and motives, and may lead to different market reactions. Given those reasons, this study will further examine factors influencing decision to issue additional shares by separating different forms of issuance as a robustness check. The results for robustness check are presented in Table 5 below. 
Table 5: Regression results for different issuing forms

\begin{tabular}{|c|c|c|c|c|}
\hline \multirow{2}{*}{$\begin{array}{l}\text { Independent } \\
\text { variables }\end{array}$} & \multicolumn{2}{|c|}{ Rights } & \multicolumn{2}{|c|}{ Dividend or Bonus shares } \\
\hline & Coefficient & $d y / d x$ & Coefficient & $\mathrm{dy} / \mathrm{dx}$ \\
\hline SIZE & $\begin{array}{c}0.213 \\
(0.71)\end{array}$ & 0.016 & $\begin{array}{l}0.421^{\text {** }} \\
(2.06)\end{array}$ & 0.095 \\
\hline ROA & $\begin{array}{l}0.044^{*} \\
(1.87)\end{array}$ & 0.003 & $\begin{array}{l}0.138^{* * *} \\
(3.76)\end{array}$ & 0.031 \\
\hline REVG & $\begin{array}{l}0.002^{* *} \\
(2.01)\end{array}$ & 0.0001 & $\begin{array}{c}0.000 \\
(0.03)\end{array}$ & 0.000 \\
\hline MB & $\begin{array}{l}-0.438^{*} \\
(-1.71)\end{array}$ & -0.034 & $\begin{array}{l}0.185 \\
(1.18)\end{array}$ & 0.042 \\
\hline MHold & $\begin{array}{l}-1.168 \\
(0.156)\end{array}$ & -0.091 & $\begin{array}{l}0.360 \\
(0.77)\end{array}$ & 0.082 \\
\hline DA & $\begin{array}{l}0.000 \\
(0.03)\end{array}$ & 0.000 & $\begin{array}{l}0.012^{*} \\
(1.68)\end{array}$ & 0.003 \\
\hline DIV & $\begin{array}{l}-5.073^{* *} \\
(-1.99)\end{array}$ & -0.393 & $\begin{array}{l}-5.710^{* * *} \\
(-4.45)\end{array}$ & -1.295 \\
\hline _cons & $\begin{array}{l}-2.462 \\
(0.161)\end{array}$ & & $\begin{array}{l}-4.538^{* * *} \\
(-3.33)\end{array}$ & \\
\hline Observations & \multicolumn{2}{|c|}{495} & \multicolumn{2}{|c|}{495} \\
\hline Wald $X^{2}(7)$ & \multicolumn{2}{|c|}{17.27} & \multicolumn{2}{|c|}{43.34} \\
\hline Prob(F-statistic) & \multicolumn{2}{|c|}{0.016} & \multicolumn{2}{|c|}{0.000} \\
\hline Rho & \multicolumn{2}{|c|}{0.016} & \multicolumn{2}{|c|}{0.007} \\
\hline
\end{tabular}

Notes: the notations ", "* and "** denote the significance levels of $10 \%, 5 \%$ and $1 \%$, respectively; z-statistics are robust z-statistics after correcting for heteroskedasticity shown in parentheses.

Two points are worth noting from the results. First, similar to the main model company size (Size), returns on assets (ROA), revenue growth rate (REVG) and dividend ratio (DIV) are still the same sign although in two cases the coefficients turn to statistically insignificant at the traditional levels (i.e., Size for rights issuance and REVG for Dividend or Bonus shares). Yet, the coefficient of variable of market to book value ratio $(\mathrm{MB})$ is negatively significant at the $10 \%$ level for the group of companies using rights issuance, while the variable of financial leverage (DA) is positively significant at the $10 \%$ level for the companies implementing stock dividend and bonus shares.

Results from the variable of market to book value ratio show that as the company's market stock price reaches at higher levels, the company is less likely to do equity offerings by issuing rights. If the company issues rights at the times when stock prices peak, investors may perceive that stock prices are overvalued, and that managers are trying to take advantages of this, they due to information asymmetry therefore may sell the stocks leading to a decrease in stock prices. This result is consistent with the argument that decision to issue additional shares may not be motivated by the market timing theory (DeAngelo, DeAngelo, \& Stulz, 2010). With regard to the result of financial leverage ratio variable, it shows that if the company has a higher financial leverage ratio, the probability that the company choose to do equity offerings by the form of stock dividends (bonuses) increases. This could be explained that since investors tend to underestimate the heavily indebted companies, issuing more shares by rights is a bad choice for these companies. Instead, those companies may choose stock dividend or bonus shares as form of equity offerings to reduce interest expenses or ensure a balanced ratio between debt and equity.

\section{Conclusion}

In short, the study has contributed the empirical evidence on factors influencing the decision on seasoned equity offerings of Vietnamese listed companies. The findings show that return on asset, revenue growth, firm size positively significantly stock offerings decision of companies, while the dividend payment ratio has a negative impact on the decision. These results partly help to confirm the appropriateness of growth opportunity theory for the listed companies in 
Vietnam stock market. Regarding the equity-offering forms, stock bonuses or stock dividends are more likely chosen by companies with a high rate of return, a large size, a high debt ratio and a lower dividend payout ratio. Rights issuance is more likely to be selected by companies with a high revenue growth rate; meanwhile it is less likely to be conducted by companies with a high market value/book value ratio. Those results have several implications for both corporate governance, policy makers and investors.

\section{References}

Abraham, R., \& Harrington, C. (2011). Seasoned equity offerings: Characteristics of firms. International Journal of Business, Humanities and Technology, 1(3), 26-33.

Alt1, A., \& Sulaeman, J. (2012). When do high stock returns trigger equity issues? Journal of Financial Economics, 103(1), 61-87.

Baker, M., \& Wurgler, J. (2002).Market timing and capital structure. The journal of finance, 57(1), 1-32.

Bo, H., Huang, Z., \& Wang, C. (2011). Understanding seasoned equity offerings of Chinese firms. Journal of Banking \& Finance, 35(5), 1143-1157.

Barclay, M. J., \& Smith, C. W. Jr. (1995). The maturity structure of corporate debt. The Journal of Finance, 50(2), 609-631.

Chikolwa, B., \& Kim, J. (2009, August). Determinants and market impact of seasoned equity offerings: the case of A-REITs. Paper presented at the 22nd Australasian Finance and Banking Conference.

Choe, H., Masulis, R. W., \& Nanda, V. (1993). On the timing of new equity issues: theory and evidence. Journal of Empirical Finance, 1(3), 31.

DeAngelo, H., DeAngelo, L., \& Stulz, R. M. (2010). Seasoned equity offerings, market timing, and the corporate lifecycle. Journal of Financial Economics, 95(3), 275-295.

Elliott, W. B., Koëter-Kant, J., \& Warr, R. S. (2008). Market timing and the debt-equity choice. Journal of Financial Intermediation, 17(2), 175-197.

Gujarati, D. N. (2004). Basic Econometrics (4th ed.). New York, NY: McGraw-Hill.

Gul, S., \& Cho, H. R. (2019). Capital Structure and Default Risk: Evidence from Korean Stock Market. Journal of Asian Finance, Economics and Business, 6(2), 15-24. https://doi.org/10.13106/jafeb.2019.vol6.no2.15
Huang, Z. (2012). Seasoned equity offerings in China (Doctoral dissertation). SOAS, University of London, London, England.

Ha, D. T. T. (2017). Seasoned equity offerings evidence in Vietnamese stock market (Doctoral dissertation)/ University of Economics Ho Chi Minh City, Ho Chi Minh City, Vietnam.

Jenson, M. C., \& Meckling, W. H. (1976). Theory of the firm: managerial behavior, agency costs and ownership structure. Journal of financial economics, 3(4), 305-360.

Jung, K., Kim, Y. C., \& Stulz, R. (1996). Timing, investment opportunities, managerial discretion, and the security issue decision. Journal of Financial Economics, 42(2), 159-185.

John, K., \& Williams, J. (1985). Dividends, dilution, and taxes: A signalling equilibrium. The Journal of Finance, 40(4), 1053-1070.

Loderer, C. F., \& Mauer, D. C. (1992). Corporate dividends and seasoned equity issues: An empirical investigation. The Journal of Finance, 47(1), 201-225.

Myers, S. C. (1977). Determinants of corporate borrowing. Journal of financial economics, 5(2), 147-175.

Myers, S. C. (1984). The Capital Structure PuzzleThe Journal ofcapital structure puzzle. J. Finance, 39(3).

McLaughlin, R., Safieddine, A., \& Vasudevan, G. K. (1996). The operating performance of seasoned equity issuers: Free cash flow and post-issue performance. Financial Management, 41-53.

Nguyen, C. T., Bui, C. M., \& Pham, T. D. (2019). Corporate Capital Structure Adjustments: Evidence from Vietnam Stock Exchange Market. Journal of Asian Finance, Economics and Business, 6(3), 41-53. https://doi.org/10.13106/jafeb.2019. vol6.no3.41

Rajan, R. G., \& Zingales, L. (1995). What do we know about capital structure? Some evidence from international data. The journal of Finance, 50(5), 1421-1460.

Virolainen, M. (2009). Macro and micro determinants of seasoned equity offerings and issuer stock market performance (Master's thesis). Helsinki School of Economics, Helsinki, Finland.

Vu, V. T. T., Phan, N. T., \& Dang, H. N. (2020). Impacts of Ownership Structure on Systemic Risk of Listed Companies in Vietnam. Journal of Asian Finance, Economics and Business, 7(2), 107117. https://doi.org/10.13106/jafeb.2020.vol7.no2.107

Vijayakumaran, S., \& Vijayakumaran, R. (2019). Debt maturity and the effects of growth opportunities and liquidity risk on leverage: Evidence from Chinese listed companies. Journal of Asian Finance, Economics and Business, 6(3), 27-40. https://doi.org/10.13106/jafeb.2019.vol6.no3.27 